\title{
A Spiritual Journey
}

\section{Embarking on a Personal Journey}

It was a straightforward concept, really. So obvious that as soon as I heard it, I knew in my very core that it was of paramount importance-and that I had arrived.

I was between jobs and had only been back in London a day or so, after spending almost two and a half months in New York, when I asked a friend if he could get me an appointment with Dr Martin Lings. Over the previous seven years I had read all of Dr Lings' published books on religion per se and on Islam-often more than once-though none of his books of poetry or art and calligraphy yet. I had also read several of his teachers' and peers' writings, having come to hear of these writers from newly made friends in England after moving there from Lebanon in 1987 as a young economics graduate.

The reason for my visit was that I had been feeling a strong desire to be closer to God for many years, and I thought Dr Lings might be able to help. While in New York, I had finally come to the conclusion that no matter how much knowledge I acquired by reading the most exceptional books, I still needed help putting a plan in place to actually start the journey towards God in earnest.

For a long time, I thought I could do it on my own. After all, it was not like I was looking to convert to a new religion or anything, as I was born and raised Muslim and had always maintained a practice of sorts, and a

L. El-Ali, No Truth Without Beanty, Sustainable Development Goals Series, https://doi.org/10.1007/978-3-030-83582-8_1 
connection. But I cherished my independence and was averse to the idea of engaging a "live" teacher, as opposed to one that only spoke to me through a book, as it would inevitably imply engagement with a community of some kind that must exist around every active spiritual teacher. I would no doubt bump up against an expectation to conform to many outward aspects of behaviour that were bound to clash with who I am, both culturally and personally.

But while in New York, the thought of "I must go see Dr Lings when I get back to London" entered my head at some point and remained lodged there, and somehow I was able to eventually stop sweating the small stuff, as it were, and take the step.

It was Thursday, the 28th March of 1996, and exactly one week after my return when I visited Sidi Abu Bakr, ${ }^{1}$ as everyone in his immediate circle called him then, at his house in Westerham, in the county of Kent in south-east England. He was 87 years old. Once we had sat down I thanked him for seeing me, to which he promptly replied that I must tell him how he could help. I did just that, describing my need to move closer to God, how I had read his and similar books, and how I could do with some guidance. This time he responded by telling me his own story, how he ended up making the commitment I was now considering, and I noted as he spoke that he was 29 years old at the time-the same age I was then. At the end he asked me if I had any questions and after a brief exchange, the meeting was over and it was time for us to have tea with his wife, Sayyida Rabi'a (aka Lesley).

It was towards the end of tea, after a relaxed but far-from-frivolous conversation, that Sidi Abu-Bakr made the remark that struck me, and which I realise now has been a dominant feature of my journey and evolution.

He said: "Our way is not so much Islamic as Qur'anic."

As soon as I heard those words, I knew without a shadow of a doubt that somehow, I had found the right path. I had always been quite particular about how the adjectives Islamic and Muslim were used, often feeling

\footnotetext{
${ }^{1}$ Sidi is literally "my lord" in the North African Arabic dialect, and Abu Bakr was Martin Lings' adopted Arabic (composite) first name. As explained by the publisher in Lings, Martin. 2005. A Return to the Spirit: Questions and Answers. Kentucky: Fons Vitae, 85: "Traditional names are taken in many religious traditions to distinguish between a person's secular and sacred life. The term sidi (sayyida for women) is used as a term of spiritual respect. The Japanese, similarly, add the syllable '-sen' to the name of a person being addressed which indicates respect for that person's 'inner divinity'."
} 
frustrated at how interchangeably many people seemed to use them. Surely "Islamic" should be reserved for the religion itself and its unquestionable perfection and beautiful manifestations, while "Muslim" is the adjective to be applied to us human beings and all our flawed productions! But on hearing that short sentence, I immediately understood that I had been fussing about the wrong thing. I had been nonetheless placing too much emphasis on Islamic religious institutions, whereas what I should have been concerned with is God's word, first and foremost. This is because religious institutions and associated fields of study, such as jurisprudence and law, are ultimately the work of us human beings in all our failings as well as our strengths, so what is "Islamic" is ultimately defined over time by Muslims themselves - no doubt doing our best-but not by God. God's only direct offering, all Muslims agree, is what we believe to be the perfectly preserved Qur'an itself as communicated by the archangel Gabriel to the prophet Muhammad in the seventh century over the course of 23 years.

Over the next five years, I committed to reading the Qur'an more thoughtfully during the fasting month of Ramadan, as opposed to rushing through just to finish it within the month, as had sometimes been the case. Up until then I had read it sporadically and only in the original Arabic, apart from sections I once read in English for one of the Civilization Sequence courses at the American University of Beirut that were required for all arts and sciences majors, a course which also covered Christianity and Judaism. But now I wanted to be sure I was not missing anything and the quickest way to do that, I thought, would be to read an English translation of the Qur'an side by side with the Arabic (as opposed to consulting an Arabic dictionary), given that English is effectively a second mothertongue for me and my English vocabulary was far richer than my classical Arabic one. This meant being incredibly disciplined and focused if I was to keep the exercise going daily for a full month while fasting during the day, especially after I got back to work as a fund manager and later as an investment strategist, which meant 10 to 12 hours of being in the office five days a week.

Dr Lings was recognised as one of the world's greatest Arabists as well as a leading authority on Shakespeare and professor of English, having majored in English literature at Oxford University at both undergraduate and graduate levels, and having obtained a doctorate in Arabic studies from the University of London's School of Oriental and African Studies. But when some of his spiritual mentees would suggest he consider 
producing a new translation of the Qur'an into English, he would say that there was no need ${ }^{2}$ because Marmaduke Pickthall's translation was very good.

I once heard him comment, though, that the much-repeated noun in the Qur'an that Pickthall translates as "those who ward off evil" could have been more simply translated as "the pious". I have also heard him say that one thing he regretted about Pickthall's translation, and that he would have done differently, is that he doesn't translate "Allah" to "God" but keeps the Arabic word throughout the English text. Clearly, Dr Lings was recognising the fact that to a complete newcomer who knew little or nothing about Islam, this might give the false impression that "Allah" is the particular deity worshipped by Muslims, as opposed to simply the Arabic word for "God". My guess is that Pickthall kept "Allah" as is because he felt attached to how it sounded in the original (he had adopted Islam as his religion), but this does not serve the purpose of optimal communication through translation. Pickthall's decision not to translate "Allah" is ironic because at the same time, he does (correctly) translate the Arabic plural word muslimun into "those who have surrendered (unto God)" as opposed to "Muslims", as such references in the Qur'an were unquestionably to all those who surrender to God regardless of their perceived religious affiliation. To underscore this definition and leave no doubt among future generations as to whom God considers to "have surrendered" to Him, the Qur'an goes so far as to declare the pre-Islamic Abraham himself one "who had surrendered", or muslim in Arabic (3:67), and the same goes for the disciples of Christ $(3: 52,5: 111)$ who predated Islam by more than 600 years, among others. This broader meaning of the Arabic muslim or muslimūn (pl.)-as an adjective rather than a noun-would have been evident to Muhammad's own generation also because the religion he established was not given the official name of "Islam", meaning "Surrender" or "Submission" (to God), till the very final passage of the Qur'an (5:3) revealed at the end of the 23-year process of revelation.

\footnotetext{
${ }^{2}$ In subsequent years, Dr Lings appears to have changed his mind about the need for a new translation of the Qur'an, and was in fact working on such a translation when he passed away in 2005. It was posthumously published in 2006 and presents his translations of Qur'anic verses as extracted from these previously unpublished writings and from all his other publications, with the Arabic original on the opposite pages. See Lings, Martin. 2007. The Holy Qur'an: Translations of Selected Verses. Cambridge, England: The Royal Aal Al-Bayt Institute for Islamic Thought and The Islamic Texts Society.
} 
Pickthall's translation is in a formal, classical English style, so it is not a smooth experience for the modern reader, although it remains my go-to complete translation more than 20 years later, having compared it with all others I know of. It maintains an extraordinary degree of fidelity to the original text's structure, but in another language like English that ends up sounding clunky in many instances. And while it conveys the Arabic more accurately than most, the choice of wording at times is surprising, which makes me wonder if he would not have chosen differently had he lived among us today and been exposed to how easily an innocent word can have unintended consequences. Here I am thinking in particular of how he sometimes translates what essentially means allies or protectors as "friends" $(5: 51,5: 57)$, although at times he goes for the better option of "protecting friends" (6:14). But I very much like the introductions he has written to many of the chapters, which provide the context for a given chapter or explain some particular aspect of it, such as where its title came from. I just wished someone had thought to publish the Arabic original opposite each page of Pickthall's translation, as juggling two heavy books side by side with one index finger on a precise location in each book simultaneously and for hours at a time proved to be a tricky balancing act! As for the Arabic Qur'an, which comes in many hard-to-read though beautiful calligraphic styles, I would simply say that it can make all the difference to a reader to get hold of a copy in an easy-to-follow font that increases the chances of correct reading, and I was fortunate enough to have one: every reader of Arabic will know what I mean regarding the challenge of knowing where one word ends and the next one begins in calligraphic script, and which vowel should accompany a letter to ensure the correct meaning is extracted from the reading.

I never had any major issues with what I was reading in the Qur'an during those years, although a handful of verses in the English really were difficult to understand, which means that the Arabic was even harder. Taking the experience of reading the Qur'an as a whole while stopping to mull over both the verses and their translation, my faith only deepened. 


\section{The Journey Continues, in a More DisTRESSING ENVIRONMENT}

Like many people, I only started to hear of the more disturbing verses attributed to the Qur'an after September 11, and today it is pretty much everywhere I turn. They emanate from the East and the West, from Muslims and others, from politicians to religious leaders to lay people to extremists of all stripes, from the daily news to the latest TV series to anywhere you look on the internet. Who in the West today has not heard of the supposed 72 virgins awaiting a Muslim martyr (presumably male) in heaven? And what Muslim in any country on earth has not now heard of the verse allegedly telling husbands they can beat their wives?

It has been 18 years of this barrage in the 24/7 digital world we now live in. This has led some Muslims to distance themselves or turn away from their religious heritage altogether, while others have reacted with a combination of sadness, frustration, withdrawal and anger at what their beloved religion has been reduced to. Only extremists seem to relish the current atmosphere, and even thrive in it, whatever their background.

As my own personal journey has continued, I have also looked for answers to the seemingly inexplicable spread of such unsavoury ideas within and about Islam. I have searched for answers through investigative reading and experiential learning, the latter made possible by my work over the past 14 years in conflict resolution, peacebuilding and social entrepreneurship internationally. I have come to learn that the egregious ideas within Islam began to spread in earnest in the second half of the twentieth century in the Middle East, and that by the 1980s had been successfully exported to other regions. And that these ideas have continued to gain force since then, often displacing centuries upon centuries of more harmonious Islamic practice that had been perfectly at ease with a wide array of local cultures across the globe, replacing it with a spiritually dry version, one that is moreover increasingly homogenous in such visual manifestations as clothing, mannerisms and socio-religious customs.

\section{The Challenge of Hadith vs QuR'AN}

I have also come to realise that most egregious claims within Islam can be attributed not to the Qur'an but to hadith, the collection of reports about the sayings and actions (the latter separately referred to as sunna) of the prophet Muhammad. This is no small technicality, for all schools of 
Islamic jurisprudence draw heavily on hadith in formulating their moral guidelines (sharia) and establishing their Islamic laws (aka sharia law).

This set off an immediate alarm bell for me: the Muhammad of the Qur'an is a gentle being who is always concerned for others, ${ }^{3}$ and his biography based on the earliest sources written by Dr Lings ${ }^{4}$ himself had moved me to tears every time I neared its end, which of course recounts Muhammad's own peaceful end. In addition, all the hadiths I had ever heard or read about the Prophet were inspiring and beautiful, so where were all these ugly and sometimes bizarre ones coming from?

When I discovered that the most highly regarded collection of hadith, by Bukhari, had required the venerable man to sift through no less than 600,000 reports as part of his monumental effort (which took him 16 years), ${ }^{5}$ I began to see one possible source of the problem, not least because Bukhari was born 178 years after the Prophet's passing in the year 632 .

In Chaps. 2 and 3, entitled "Hadith Corpus" and "Hadith Content" respectively, I have tried to describe the key facts relating to hadith that I

${ }^{3}$ See Lang, Jeffrey. 1995. Struggling to Surrender: Some Impressions from an American Convert to Islam. Maryland: Amana Publications, 75-76, where the author sums it up beautifully: "When we read the Qur'an, however, much of that [worldly aspects] fades into obscurity, as does the character of the Prophet himself. What remains is a man who is very reluctant to insult his guests when they have stayed too long (33:53), who deals gently with his followers after the failure at Uhud (3:159), who perhaps too readily excuses others (9:43), and who prays for the forgiveness of his enemies (9:80). He is described as kind and compassionate (9:128), and as a "mercy" to believers (9:61) and to all beings (21:107). His anxiety and concern for the success of his mission and the fate of his fellow man $(16: 37 ; 16: 127 ; 18: 6)$ is such that he has to be reminded frequently that his duty is only to deliver the Message $(6: 107 ; 11: 12)$, that only God guides people $(2: 272)$, and that it is not in his power to guide those he loves if God has decided differently (28:56). This is only a partial glimpse of Muhammad, but it is significant that this is the side of his character that is exposed in the Qur'an.”

${ }^{4}$ Lings, Martin. 1988. Muhammad: His Life based on the Earliest Sources. London: Unwin Hyman Limited.

${ }^{5}$ Stowasser, Barbara Freyer. 1994. Women in the Qur'an, Traditions, and Interpretation. New York: Oxford University Press Inc.,105 and Brown, Jonathan. 2014. Hadith: Muhammad's Legacy in the Medieval and Modern World. London: Oneworld Publications, 32. And as the author relays in his Brown, Jonathan. 2015. Misquoting Muhammad: The Challenge and Choices of Interpreting the Prophet's Legacy. London: Oneworld Publications, 44, Ibn Hanbal's (d. 855) great collection contained 27,000 reports (of which a quarter are repetitions) that he sifted from 750,000 "badiths" he came across on his travels! 
have learned from some excellent books by Islamic scholars specialising in this field. This is critical information in a world inundated with all kinds of claims in the name of the Qur'anic God and His Messenger. Chapter 4 will then touch on the role of women in the development of the hadith corpus, a role that remained fairly active until the sixteenth century. A summary of badith characteristics is then given at the end of Part I, including a bulletpoint list of strengths and weaknesses. Some readers may prefer to skip straight to this summary of what hadith is and what it is not, not wanting to delve into the history and development of hadith, but if so I recommend at least glancing through the next two chapters to dissolve any doubt about where the summary comes from. The reason is simple: I feel it is better to clear the cobweb shrouding hadith before taking a fresh look at the Qur'an in the rest of this book in Parts II, III, IV and V, rather than walking through the cobweb toward the Qur'an while struggling with the web's sticky threads over our eyes, ears, and hearts.

Open Access This chapter is licensed under the terms of the Creative Commons Attribution 4.0 International License (http://creativecommons.org/licenses/ by $/ 4.0 /$ ), which permits use, sharing, adaptation, distribution and reproduction in any medium or format, as long as you give appropriate credit to the original author(s) and the source, provide a link to the Creative Commons licence and indicate if changes were made.

The images or other third party material in this chapter are included in the chapter's Creative Commons licence, unless indicated otherwise in a credit line to the material. If material is not included in the chapter's Creative Commons licence and your intended use is not permitted by statutory regulation or exceeds the permitted use, you will need to obtain permission directly from the copyright holder.

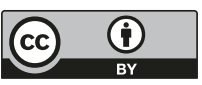

